Surviving the assault? The Australian disability movement and the neoliberal workfare state

Social Movement Studies, 9 (2), 139-154.

Karen Soldatic

Centre for Human Rights Education

Curtin University of Technology

Bentley, WA,

Email: k.soldatic@curtin.edu.au

Anne Chapman

Graduate School of Education

University of Western Australia

35 Stirling Highway

Crawley WA 6009

Email: anne.chapman@uwa.edu.au

Karen Soldatic was recently awarded her PhD on the Australian disability movement and disability policy restructuring during the Howard Years of Government (2009) and is currently working at Curtin University of Technology, Western Australia.

Anne Chapman is a Professor of Education at the University of Western Australia. Her research interests include social policy analysis, within the broader frameworkf of understanding discourse, identity and social practice in educational contexts. 


\title{
Surviving the assault? The Australian disability movement and the neoliberal workfare state
}

\begin{abstract}
:
This article provides an analysis of the key areas of struggle for the Australian disability movement during the Howard years of government. After providing an a brief overview of the Australian disability movement and its historical development, we then move to situate the struggles of the Australian disability movement within the broader context of welfare to work, one of the central tenets of neoliberal social policy restructuring. From here, three sites of struggle emerge that have been central to the Australian disability movement's struggles for representation, recognition and redistribution and principally include state re-structuring of disability open labour market supports, state legitimation of disability sheltered workshops and finally, the pensioner-categorisation of disability within social security law and policy.
\end{abstract}


Introduction

In this paper we describe and analyse the primary areas of struggle for the Australian disability movement that emerged at the national level during the Howard period of Government (1996-2007). Drawing upon a large national empirical research that involved interviews with disability movement actors, family and parent groups, disability service providers and their peak organisations, we identify, anaylse and theorise the repertoire of contention that the Australian disability movement drew upon to contest neoliberal social policy formations and articulations of disability.

There is limited work available on the disability movement situated within the field of social movement studies, and what has been discussed is dominated by research from North American and Britain (e.g Campbell and Oliver, 1996; Charlton 1998; Malhotra 2005; Shapiro 1993; Zames Fleischer and Zames 2001). Thus, it could be concluded that the Australian disability is largely under-theorised and as such, this paper provides a unique insight into the struggles occurring on the ground for some of the main actors of the Australian disability movement and new developments with increased institutionalisation of movement actors with neoliberal intensification.

The Australian disability movement first emerges as part of a global disability rights movement in the late 1960s. Founded on a common identity (Meekosha, 2002, p.72), the movement was forged with the collective 'experience of discrimination and difference' (Smith, 2003, p. 345). In line with the global disability movement, the Australian disability movement actively reframed 'disability', from a site of abjection, medicalisation and biological inferiority, to a site of social oppression and politics (Goggin and Newell 2005). The strength of the movement's reframing empowered disabled people to work collectively to contest the hegemonic practices which positioned disabled people as the deserving poor (Evans, 1989, p. 242), and worthy of pity and charity (Shapiro, 1993, p. 12). The unifying principle of mobilisation has been around the 'common need to raise a voice against hegemonic power structures' (Meekosha and Dowse, 1997, p. 65). As Zames Fleischer and Zames (2001) purport, the global disability movement directly confronted, and continues to confront, dominant and unquestioning signified representations of disabled people and 'selfserving assumptions about normality’ (Meekosha, 2002, p. 69). The disability movement as a legitimate voice, is the greatest challenge to an able-bodied society 
that has difficulties in reframing democratic participation that is truly inclusive (Meekosha 2001, pp. 226-227),.

The Australian disability movement, much like its British counterpart (see Campbell and Oliver, 1996; Martin, 2001; Oliver 1990; Shakespeare 1993), has focused on struggles for recognition, redistribution and representation (Soldatic 2009). The Australian disability movement made large gains for social rights including social security, anti-discrimination legislation and disability policy representation during its pinnacle period of activism of the 1980s (Soldatic \& Pini 2009). State sponsorship of the 1981 International Year of the Disabled (Meekosha 2002) along with the Hawke Labor Government coming to power in 1983 led to the Australian chapter of Disabled People’s International gaining formal state recognition. Within three years, numerous local networks of the movement became formalised as institutional actors around the country (Newell, 1996, pp. 429-432) and large gains were made particularly in terms of policy representation (Meekosha 2002).

By the mid-1990s, divisions within the Australian disability movement surfaced. Taking on a range of permutations the Australian disability movement has largely become segmented into what is more reflective of biosocial movements, where collective action is increasingly framed around single issues associated with the concerns of a particular impairment 'type' (eg autism, intellectual disability etc). As Hughes (2009) suggests, biosocial movements entrenches the medicalisation of the disabled body whilst simultaneously offers a politics of hope for collective identity formation around medical categorisation. For Newell (1996), however, the claim for impairment specificity has weakened the movement's collective struggles for social justice, alongside enhancing the nation state's capacity to unleash a raft of strategies to actively divide and hence, de-mobilise collective struggles common to the broader disability identity.

At the same time, women with disabilities across the country began to formalise their own networks and contest the underlying masculine struggles of the movement., revealing the complexity of their identity and the specific injustices in which women with disabilities face (Meekosha 2002). Control of the reproductive sphere and the 
representation of disabled women as unfit for the reproduction of the nation (Meekosha and Dowse 1997; Soldatic and Biyanwila 2006) were key issues neglected by the broader movement where the right of work and the politics of distribution have dominated the movement's collective struggles for justice.

By 1999, as a reflection on the movement's gains and loses, the leading disability feminist Helen Meekosha (1999, p. 1) argued that for many disabled people, living in Australia at the turn of the century was like living in a 'war zone'. Gerard Goggin and Christopher Newell, concurred with this position, articulating 'disability' as a state of social apartheid (Goggin and Newell, 2005). Yet many of the gains made during the 1980s were wound back with the advent of neoliberalism as the governing hegemonic ideology. With neoliberalism's intensification, the movement's institutionalisation became further entrenched as advocacy groups were embedded within state-contractual relations, which sought to actively constrain their representational actions imposing strict media controls as a condition of funding (edia (Ohlin 1999). Advocacy groups were increasingly reframed by the Howard Government as political lobbyists, rather than civil society actors denying any potentiality for dissent and protest. For the disability movement, this assualt was primary driven by the Howard Government's commitment to neoliberal workfare which recategorised 'disability' and withdrew social entitlements and state sponsored structures of social provisioning that promoted inclusion, representation and participation.

\section{From Keynesian welfare to neoliberal workfare}

Workfare is a key domestic social project of neoliberal global restructuring (Peck 2001, 9-10). The concept first surfaced in North America under the Reagan administration but came into full effect in the US during the Clinton Administration with the passage of the Personal Responsibility and Work Opportunity Reconciliation Act 1996 (Abramovitz, 2006, p. 339). Workfare is now part of an international project (Haylett, 2003, p.765) promoted through global policy institutes such as the OECD and IMF (Humpage, 2007, p.220). In the last ten years, most Western nation states have undertaken some form of welfare restructuring to reflect the institutional 
requirements of a workfare state (Peck, 2001, pp. 9-10). In the UK, the Blair Labour Government developed its ‘making work pay’ strategy and its New Deal policy (Cook et al. 2001; Finn, 2000) and countries such as Canada (Peck 2001) and Australia (Shaver, 2001) have taken similar paths.

Goodin (2002) has suggested that Australia has had the most articulated workfare policy in the western world. Australian workfare restructuring has established new understandings of citizenship (Shaver, 2002, p. 339). Citizenship 'rights and entitlements' has have been redefined as citizenship 'responsibilities and obligations' (Goodin, 2002, p.579) which has drawn upon neo-conservative discourses of social responsibility to curtail individual freedoms usually embedded within neoliberal citizenship framings of state and citizen (see Maddison and Martin, this volume). This is reflected in the neoliberal populist mantra of 'no rights without responsibilities' (Fiske \& Briskman, 2007, p.50), and in Australia has been most clearly expressed in the Howard Government's mutual obligation program. Under this policy framework, access to social entitlements is no longer based on need or necessity. Citizens receiving welfare are forced to earn their social entitlements through participation in the labour market (Peck, 2001, p. 9), as paid work is promoted as the highest form of citizen responsibility (Lister, 2001, p. 91).

Workfare, therefore, signifies a reordering of the labour market and welfare nexus (Peck, 2001, 51). Catch words, such as flexibility, casualisation and productivity, are coupled with discourses of mutual obligation. In Australia, the Howard Government's 'mutual obligation’ policy and ongoing legislative reform emulated global hegemonic trends in neoliberal restructuring. The Howard Government's legislative amendments to disability social entitlements and social provisioning fully articulated the neoliberal reimagining of welfare as workfare (see Carney, 2007). The passage of the Welfare to Work Act 2005 (Cth) occurred within one day of the passage of the Work Choices Act 2005 (Cth), the Howard Government's long awaited neoliberal labour relations agenda (see this volume). Labour market flexibility, casualisation, and worker insecurity, driven by the neoliberal rationality of market rule, reflected the accumulation of a range of authoritarian social policies, which dramatically affected disabled Australians. 
The centrality of work within neoliberal workfare citizenship debates is constructed on able-bodied, masculine notions of care, work and productivity. People receiving welfare are denied forms of social participation including care for others (Haylett, 2003; McInnes, 2007). For many disabled people who have extensive personal care needs, and especially in the case of women with disabilities who may provide multiple forms of time intensive care, for themselves and others, workfare is a highly pervasive policy strategy further stigmatising the subjective experience of the self and the body. Shaming into compliance is a common feature of its coercive regulating regime. The lack of a job is articulated as a private moral failure. Moralising structural disadvantage reinforces existing social divisions (Martin, 2007, p. 1), whilst re-constituting new social hierarchies. For disabled people, the deliberate 'misrecognition' of labour market discrimination further entrenches their structural position of poverty, which is more pronounced for women with disabilities (Salthouse, 2005, p. 1). Other discriminatory issues, such as accessible transport or personal care support within the workplace, that facilitate disabled people's employment participation are rarely acknowledged in workfare debates.

Workfare is an ongoing policy project, one that, like neoliberalism, is continually moving (Peck, 2001, pp. 9-10). Ongoing policy testing, trialling and change are synonymous with workfare restructuring, particularly for disability. The Howard Government's workfare agenda, largely in line with the global consensus of workfare restructuring is, however, distinctly local. For the disability movement, three key areas of contention emerged during the Howard period of Government: first, the restructuring of the "disability open employment supports and programs”; secondly, the legitimisation of "sheltered workshops", and finally, the re-categorisation of disability with the passage of the Employment and Workplace Relations Legislation Amendment (Welfare to Work and Other Measures) Bill 2005 (Cth). The remainder of this article addresses workfare restructuring of these three key sites of contention, outlining the policy strategy and its intent, forms of resistance and contestation that emerged as a result of workfare restructuring to disability programs. Unfortunately, within all three sites, the Australian disability movement was unable to withstand the neoliberal attack of workfare and these measures still remain. 


\section{Reform and resistance or cooption and complicity? Workfare restructuring of disability employment services}

The right to work has been central to the Australian disability movement's struggles for justice. After extensive campaigns, the disability movement won numerous concessions and by the mid-1980s the advent of legislation (Commonwealth Disability Services Act 1986) established a large network of disability open employment support services. These services were at the forefront of meeting some of the disability movement's key aspirations, demands and campaigns around work, employment and inclusion (Clear 2000). In a unique social experiment, the state intervened in labour markets whilst redistributing resources to services that were largely governed in the interests of disabled people (Clear and Gleeson, 2002, p. 50).

After 10 years of neoliberal workfare restructuring (1996 - 2005), the disability movement's former aspirations have been largely undermined. Diminishing levels of control, exclusion from the policy process and the individualisation of service delivery systems characterise this period (see Dowse, 2007). As a consequence, services have largely drifted away from their social base. Services were aware of their transformation under the Howard Government's workfare reforms and clearly articulated their shift from the role of advocate to that of human resource manager. The CEO of the disability open employment peak organisation, ACE, commented on this as follows:

Initially there would have been a focus on advocacy in terms of employment on behalf of people with disability with respect to employment. The approach would have been different. Now the employer is our customer and we are trying to meet their recruitment needs. (December 2005).

Services' co-option and complicity with the Howard Government's workfare agenda was the result of long running funding reforms. Part of the funding reform process involved the establishment of a range of committees, the most prominent being the Case Based Funding Reference Group. As the group’s name suggests, the initial reform processes focused upon the strategic re-orientation of services' funding. This involved the realignment of a collective based provision, commonly referred to as a “block grant model”, to a highly competitive individualised funding model where 
fiscal resources were allocated to services premised upon contractual program outcomes formulated against a highly medicalized classification regime of individuals with impairments. The neo-liberal focus on outcomes can be seen as a deliberate ideological strategy to disguise structural processes of exclusion and inequality (Skeggs, 2004, p. 82). Consultative membership of the group was dominated by large charitable organisations and their peak organisation The Australian Council for the Rehabilitation of the Disabled (ACROD). A diverse group of open employment services were also included. Only one organisation within the disability movement's advocacy network gained representational status.

As work began on developing a funding formula a number of tensions emerged, clearly along historical lines. Disability open employment services increasingly contested ACROD's representative role and consequently formalised their own network to begin lobbying as a collective coalition to exert their interests.

Representation dominated by two powerful lobby groups alienated the disability movement's only representative, who eventually walked out of the negotiations (Research Participant, September 2005). As the disability movement has long argued, equality in policy representation is central to the democratic decision making process and to disabled people's social inclusion (Charlton, 1998), which 'requires innovative policymaking processes that are open, transparent and accountable' (Goggin and Newell, 2000, p. 131). Central to these processes of inclusion is the 'necessity of political equality in exercising that control (to ensure that popular majorities do not override respect for a diversity of minority voices)' (Maddison 2007, p. 27). Meekosha (2001, p. 225) refers to this as the politics of presence, where disabled people are part of, and included within, the representative process.

After three years of negotiation, a trial was established over 18 months. The results of the first round of trials created a groundswell of action, encouraging a moment of renewal within the disability movement. New alliances were formed, whilst old ones became reactivated. Services' re-targeting of fiscal and service resources under CBF, to what Evans (1989, p. 249) refers to as the most 'able of the disabled', became the driving force for new coalitions. As Tilly (2006, p. 41) suggests, social movements tend to work within their script, through small, yet ongoing, innovations. Services, families/carers, and disability advocacy groups, well practiced in lobbying local 
parliamentarians, began to make a number of claims. Small, local civil society groups, loosely connected to the disability movement and free from bureaucratic constraint, took their local practices to the national level. Groups such as the Western Australian Friends of Post-School Options bypassed the policy process and engaged directly with national politics lobbying local parliamentary representatives (Senate Hansard, 1999, pp. 9727-9730).

Representing a diverse set of voices, including parents, disability open employment services, and disability advocacy organisations, a new informal civil society group, the National High Support Needs Network (NHSNN) was formed. The NHSNN directly involved formal members of the CBF Reference Group. As dissenting voices within the CBF Reference Group, this new loose network 'provide[d] a forum for the realisation of new identities' (Tucker, 1991, p. 78). As activists within the policy process (see Yeatman, 1990, p. 16), they were able to achieve a greater sense of agency to support their claims. Sitting 'alongside, but outside of the bureaucratic structure of the state' (Cohen, 1983 in Tucker, 1991, p. 78), opened up new democratic structures for mobilisation and contestation.

The growing dissent could not be contained and a range of concessions were won. The movement's claims for expanding the assessment entry criteria to curtail services' growing practice of retargeting resources at the most 'able of the disabled' was also met. A new trial commenced with a fiscal allocation of $\$ 6$ million (Anthony, 2000, p. 1). Upon completion of the trial the Howard Government, committed to restructuring disability social provisioning, undertook extensive national consultations with a view to fully implementing the CBF reforms (Australian Health Associates, 2002). Disability services and advocacy groups actively participated in the consultation process, putting forth a range of recommendations (FaCS 2003). The state conceded to one of the movement's key demands and sheltered workshops and disability open employment services were separated into two discrete funding structures. Open employment services would operate under a different funding structure. Supplementary funding measures were also implemented requiring additional resources (Budget Estimates Committee for Community Affairs, 2003, pp. 196-232). 
The Howard Government however was growing impatient with the funding reforms due to the impost it created on its ideological commitment to workfare. In direct opposition to the new and emerging dissenting civil society voices, trials began for disability employment support within mainstream providers (Commonwealth Department of Employment and Workplace Relations (DEWR) 2004). There was no consultation with disability advocates or potential users. Disability employment services, sheltered workshops and open employment were also largely kept in the dark (ACROD 2004b). The trial was administered outside of the state administrative agency responsible for disability policy (FaCS). Disability was now 'unofficially' within centre stage of the Howard Government's primary neoliberal administrative branch, the Department of Employment and Workplace Relations (DEWR).

Thus, the small concessions conceded with the new funding models were largely lost with the full advent of neoliberal workfare. Disabled people and their movement lost all control of disability open employment services. Disabled people’s marginal representation was completely alienated from the new Commonwealth department. The new peak organisation for disability open employment services, Australian Competitive Employment, founded from the struggles within the funding reforms, became the leading state consultative body and in turn, marginalising the institutional arm of the disability movement from policy processes.

\section{Becoming respectable: Rebranding sheltered workshops}

Sheltered workshops played an integral role in the Howard Government's disability neoliberal workfare agenda. Outside of the realignment of funding formulas in line with the neoliberal principles of competition, markets and individualism, sheltered workshops gained a new level of status and legitimisation. In collaboration with ACROD, a large transnational consultancy firm (KPMG) was contracted to review sheltered workshops as part of a rebranding strategy. The final report, A Viable Future: Strategic Imperatives for Business Services (2000), articulated a new 'vision' for sheltered workshops, positioning them as a commercial business enterprise, providing quality employment for disabled people (FaCS, 2000). 
To implement the recommendations, Nobby Clark, the former CEO of one of Australia’s leading financial institutions, National Australia Bank, chaired a newly established reference group to further the recommendations. The role of capital in shaping disability policy embedded markets as the governing logic of sheltered workshop reforms. It also provided global consultancy groups such as KPMG and Pricewaterhouse Coopers with ongoing access to state resources over coming years, further privatising public resources ${ }^{1}$. Engaging a leading figure within Australian capital, built legitimacy for sheltered workshops through processes of rebranding which sought to disguise sheltered workshops' historical legitimisation crises with the disability movement and some members of the labour movement. Nobby Clark, as a key player within Australian capital played a leading role in the redevelopment of sheltered workshops as Business Services. Rebranding sheltered workshops as Business Services was of strategic importance for the legitimisation process as it blurred the historical contingencies of past exploitative practices. Even the policy elite were aware of this strategy within the naming process: 'If you are talking in world terms or even in a state, I mean what are business services? It doesn't resonate with anything, does it? (Telephone interview with Commonwealth Policy Staff, December 2005).

The rebranding of sheltered workshops as business services represented only one strategy in building processes of legitimation. In addition to increased resourcing, the Report's recommendations supported the application of productivity based wages to address the long-standing non-industrial provisions of employment for disabled workers in sheltered workshops. The proposal to introduce some form of industrial regulatory measures sparked a number of campaigns. The accumulated effects of funding reforms and the proposed increased pay rates for disabled workers had sheltered workshops predicting devastating losses in income and, as a consequence, their eventual collapse. Even though ACROD signed off on the report, the new CEO presented an alternative case to the Community Affairs Senate Committee, highlighting the impact of the barrage of neoliberal workfare restructuring on sheltered workshops. ACROD, sheltered workshops' peak organisation, conceded that providing industrial wages and conditions for their disabled workers was a necessary

\footnotetext{
${ }^{1}$ In the 2003-04 national budget approximately $\$ 7$ million was allocated to global capital as part of ongoing consultancy fees to build sheltered workshops' market viability (Community Affairs Legislation Committee, 01 June 2004, p.170)
} 
contingency to increase sheltered workshops' legitimacy (Ken Baker, CEO, ACROD in Community Affairs Senate Committee, 25 September 2001, CA4). ACROD, however, also engaged in a public campaign to marginalise and de-legitimize the longstanding demands of the disability movement. With the aim of creating divisions within the movement, ACROD began to de-legitimize the broader movement's representational role in the reform's policy processes through juxtaposing the claims of the 'many' against the 'few', and thus situating the claims of the movement as representing only a minority of disabled workers against the collective interests of sheltered workshop disabled employees (see Ken Baker, CEO, ACROD in Community Affairs Senate Committee, 25 September 2001)

Realising that their efforts to intervene in the sheltered workshop reforms were increasingly futile, two advocacy groups within the disability movement - National Council on Intellectual Disability (NCID) and Disability Employment Action Centre (DEAC) - mounted an industrial campaign for sheltered workshops to be registered through the nation state's regulatory industrial body, the Australian Industrial Relations Commission (AIRC). Such a strategy had never been tried before, and was outside the movement's 'repertoire of contention' (Tilly, 1978, p. 86) The two leading disability advocacy organisations lodged an intervention into the AIRC's Safety Net Hearings (DEAC \& NCID, 2003), with the backing of the labour movement. Sheltered workshops, with the support of families, mounted a counter campaign, engaging one of Australia’s leading corporate law firms, Blake Dawson Waldron (ACROD, 2005, p. 2). With intense negotiations between ACROD and their lawyers, along with families' claims to rights as 'secondary stakeholders' (APA, 2005, pp. 7-9), the labour movement shifted its position (ACROD 2004a, 4), leaving the disability movement's intervention unsupported. As a leading advocate for disability equity in employment articulates, the consequences resulted not only in legitimising sheltered workshops as segregated employment for disabled people, but also ensuring disabled workers' long term exploitation:

What then subsequently happened was the introduction of a dodgy wage calculation method so that you could pay the same very poor wages but have it meet the standard, the standard being a legal instrument. Really it's 
disgraceful in Australia that the ACTU stood beside the government and workshop lobby in doing that (November 2005).

Given the context of a growing authoritarian workfare state, it is difficult to assess if this 'moment of madness' (Tarrow, 1983, p.281), as a new practice of contention for the disability movement, represents a form of 'activist wisdom' (Maddison and Scalmer, 2006, p. 7). The marginalisation of the disability movement and the creation of tensions between parents and their disabled children's representative organisations, were of strategic importance to the Howard Government's overarching workfare reforms. Families had a long held claim in sheltered workshops as leading proponents of the second wave of the disability developmental movement (Dowse, 2007, p.147). In addition to supporting sheltered workshops' claims within the industrial environment, new alliances among families emerged to run a number of campaigns to directly undermine the disability movement's claims for industrial justice within sheltered workshops.

Spread across Australia, new technologies provided avenues for family collective action, previously prohibitive. The growing use of information technologies amongst rural women has increasingly seen rural women become political activists engaged with forms of social protest that blur the public/private sphere (see Pini, Brown \& Previte, 2004, p. 256). The campaigns were organised by the mother of an adult son working in sheltered workshops from a regional centre within North Queensland, but mobilised families from far Northern Queensland through to rural southern Western Australia. Under the auspices of the Australian Parent Advocacy group, two campaigns were launched: the 'Save our Services' campaign; and the 'Send Your Child to Canberra' action. The Prime Minister, John Howard, and the Minister for Disability Services at the time, Kay Patterson, received photos of potentially displaced disabled workers from around the country. Every Member of National Parliament was also emailed a list of families’ demands.

The campaigns drew on powerful moral paternalistic discourses of care and pity, feeding directly into the Howard Government's neo-conservative family and gender politics. Family mobilisation against the introduction of wages within the sheltered workshop system drew large fiscal gains and further marginalised the disability movement from the policy process. On 21 April 2004, Prime Minister John Howard 
personally guaranteed ongoing access to sheltered workshops for all employees at the time announcing that 'no one would lose their employment because of the reforms' (Howard, 2004, p. 1). Committing an additional \$99 million, the package provided 'targeted assistance' to disabled workers who were assessed as unproductive. The additional funding, along with the personal commitment by the Prime Minister to maintain existing disabled workers within sheltered workshops, was a necessary contingency in building family consensus for the broader set of workfare reforms, as a member of the policy elite recalls:

There was a lot of baggage around the broader reform agenda. There had been an unsuccessful attempt to reform eligibility for the disability support pension, and that caused a lot of alarm. The people didn't want to leave their services because they thought they would lose their pension and never be able to get back on (January 2006).

\section{The workfare puzzle: disability, social security legislation and mutual obligation}

In 1999, two months prior to the trialling of new funding formulas within disability employment services, the Minister responsible for the Australian welfare system, Senator Newman, announced the Howard Government's intent to restructure it in its entirety (Newman, 1999). State categorisations of disability were central to these proposals. The proposals envisaged in law, two new classes of disabled people $-\mathrm{a}$ fully dependent class, worthy of what Goodin et al. (1999, p, 43) refer to as liberal sympathy and charity, and a class 'somewhere in-between', receiving some state support, coupled with the discipline of the market.

The Howard Government's ideological commitment to authoritarian workfare, however, was initially curtailed, as it had not created broad hegemonic consensus for its agenda. Restricting access to the disability pension by cutting the work test criterion of 30 hours per week by half (Bills Digest 2001, 2002, 2003) was publicly the most contentious aspect. Even without broad public support, between 2001 and 2003 the Howard Government attempted to slash the key disability work criteria through legislative change on three occasions, to no avail. However, the Howard Government's re-election in 2004 with an overwhelming majority gave it control of 
both houses of parliament and consequently the power to pursue its neoliberal ideological commitment to workfare.

In preparation for the foreseeable changes, large segments of the disability movement mobilised with new coalitions emerging. The Disability Participation Alliance (DPA) dominated the political and movement landscape. Led by one of Australia's leading advocacy groups and endorsed by the new peak body for disability advocacy organisations established during the Howard Government - Australian Federation of Disability Organisations (AFDO), the alliance is symbolic of the broader disability movement's increased institutionalisation with the 'contraction of the political opportunity structure' (Minkoff, 1999, p.1672) under the Howard Government. Old enemies became new companions as a disparate group emerged. The lead disability advocacy organisation People with Disabilities Australia (PWD Australia), partnered with Australia's largest welfare lobby Australian Council of Social Services (ACOSS) in order to contest neoliberal workfare restructuring. The other two leading partners within the alliance were ACROD and ACE. Curiously, the disability advocacy organisations involved in the industrial campaigns against the sheltered workshop industry, DEAC and NCID, were excluded.

The partnering of a leading disability advocacy organisation with ACROD and ACE revealed the new divisions that had emerged within the movement, along with its increasingly diminishing power to make gains within the political opportunity structure. PWD Australia had over the years became involved in service contractual relations with the Howard Government, providing disability open employment services along with a range of other consultancies. New divisions, and the political environment, as Minkoff (1999, p. 1672) suggests, constrains social movement potentiality for contentious politics and practices. The movement's repertoire of contention had substantially diminished through re-constitutional organisational structures to survive the Howard regime. Formally recognised disability advocacy groups' agency to resist and stand outside the bureaucratic structures had been largely overtaken by the necessity to move to the 'inside', even with the possible risk of complicity. Activism from within, however, had encouraged disability advocacy organisations to take on more conservative strategies of contestation (see Smyth, 2003). It is not surprising, given this context, that the DPA alliance focused on formal 
respectable conservative strategies of political lobbying (see Mendes, 2008, p. 196), with no protest activism emerging.

Effective movement mobilisation requires the building of a common identity that summons respect for identity differences, particularly for those social movements that have experienced stigmatisation and exclusion (Bernstein, 2005, p. 59). However, the DPA alliance did not directly contest the growing stigmatisation of the disabled identity that had emerged under the Howard Government. The DPA alliance argued that disabled people were in fact the same as their normate able-bodied counterparts. The majority of the recommendations submitted to parliamentarians focused on strategies to develop the 'employability' of disabled people, in line with the hegemonic proposals of international workfare restructuring (Peck and Theodore, 2000, p. 729). Thus, as Galvin (2004, p. 343) suggests, such discursive representations by members of the disability movement fed directly into the Howard Government's workfare agenda to make disability 'disappear' from the political sphere. The DPA struggle for respect, by pitching disability through discourses of 'sameness', reaffirmed the Howard Government's 'wedge' politics of resentment to achieve hegemonic consensus within the polity for its workfare reforms (see Wilson \& Turnbull, 2001). The DPA alliance never contested or confronted the underlying neoliberal ideological assumptions of workfare, with work as the central evaluation for citizenship. Thus, despite its intensive political lobbying with members of parliament, little was gained.

The Howard Government, with the new moral consensus and hegemonic power through the electoral process, was intent on making disability disappear from the political agenda. The new governing legislative framework articulated a highly medicalised workfare agenda and, as noted above, slashed the disability work test criterion in half. State fiscal restraint was also central to this argument, citing large cost savings through denying large segments of the disability population access to forms of state social provisioning that come attached with 'disability' categorisation. This deliberate strategy of misrecognition actively denied disabled people's ongoing experiences of labour market discrimination and exclusion, along with the disabling effects of a highly medicalised service regime. One concession was gained. Disabled people on a disability pension at the time of the passage of the legislation were not to 
be assessed by the new governing criteria, offering almost 700000 disabled people across the country some reprieve.

The passage of the legislative arrangements under the Employment and Workplace Relations Legislation Amendment (Welfare to Work and Other Measures) Bill 2005 (Cth) for new people seeking disability entitlements fully articulated neoliberal workfare principles (Carney, 2007, p. 12). Mutual obligation, lower payments and rapid entry to the labour market were the cornerstone of the legislation changes. New social hierarchies of disability were institutionalised. 'Disability' as a state governing category became re-stigmatised through the moral discourses attached to the legislative reforms. The coercive mutual obligations conditions with the new recategorisation of 'disability’ were even more pronounced, however, with the subsequent passage of the Howard Government's industrial relations regulatory changes. With the final piece of the workfare puzzle, disabled people across Australia became caught between the neoliberal de/re-regulation of low wage contingent labour markets and the re-stigmatisation of their bodies, stripping access to state social provisioning which encouraged disabled people's participation and social inclusion.

\section{Conclusion}

Through examining three key areas of struggle for the Australian disability movement, this article revealed the power relations embedded in disability social relations and the ways that different actors, both collective and individual, constrained or elaborated disability as a site of political contestation. Disabled people’s broader life-worlds played an integral role in mediating disability-state relations and the power dynamics therein, which in many instances undermined the disability movement's struggles for recognition, representation and participation. Whilst families may have initially played a leading role in furthering the rights of their disabled sons, daughters and siblings, with the intensification of neoliberalism, families' articulation of mobilisation unfortunately undermined many of the gains that the Australian disability movement made during the late 1980s. 
This was most evident in the area of disability employment service provision - a key component of neoliberal workfare restructuring. Services and families joined alliances to undermine the disability movement's historical and ongoing claims for industrial justice. The families' representative politics on and about disability largely drew upon the politics of pity, the dominant moral sentiment in family representations of disability (Murray 2008). In turn, families’ discursive representations of their disabled family members fed directly into neoconservative gender politics which couples neoliberal discourses on women and families (Maddison and Martin, 2010). In turn, the claims of the disability movement were actively deligitimised and alienated from neoliberal workfare restructuring on key areas of 'disability'.

As Meekosha (2001) has argued, for the disability movement the struggles for recognition and participation are dominated by the politics of presence. Disability movement representatives need to be active members of democratic deliberations and representations on matters that both directly and indirectly concern disability (Charlton 1998). Neoliberalism, an authoritarian state regime actively marginalized the disability movement from the political process. In turn, the institutional members of the movement were in fact faced with the very real dilemma of creating alliances with historical adversaries to gain access to the political process. The need to build the movement's credibility and influence as institutional actors within an authoritarian and closing political opportunity structure was the overriding concern. This remains an ongoing dilemma for the institutional arm of all movements, and the shifting sands which are an inevitable part of the process of gaining formal state recognition as an institutional representative of a broader social movement (see Donati 1984).

Moving to the 'inside' therefore creates its own limitations and, in some respects, not only impedes the movement's repertoire of contention but can also constrain its imagination for radical movement mobilisation. Further, if not embedded in a radical politics that seeks to acknowledge, respect and recognise that unity can be achieved through diversity (Bhaskar 1993), then the disability movement risks becoming increasingly divided. The institutional arm of the movement, in its struggle for state credibility, risks becoming removed from its social base (Mladenov 2009) and, in turn, silencing the diversity of 'voices' and the broader movement's potentiality for radical democratic practices of movement mobilisation. Thus, as civil society actors, 
embedded in a complex set of state-contractual relations, the institutional arm of the movement may in fact build consent for state practices that subordinate and suppress counter hegemonic movement politics (Burawoy 2003). This is most evident in the new Rudd Government's unwillingness to unwind any of the workfare restructuring committed during the Howard era (Soldatic \& Pini 2009). In fact, the Rudd Government is seeking to further legitimise sheltered workshops through re-branding campaigns which are now re-framed as "social enterprises” (Shorten 2009). Moreover, the Rudd Government, as part of its review of pensions and social security payments has explored implementing more ‘active measures' for those people with disability still able to gain access to a Disability Support Pension, even with the tighter criteria that emerged under the Howard's welfare to work agenda (see Hamer 2009).

Notwithstanding the power of the Howard Government's neoliberal workfare reforms, and the subsequent marginalisation of the disability movement and its struggles for justice, the movement has endured, albeit in different forms. In recognition of the mostly silent struggles of Indigenous Australians with disability a formalised network has emerged. The Aboriginal Disability Network met for the first time in August 2009, establishing a national network (see PWD 2009) - a significant move given that Indigenous Australians are three times more likely to have an impairment of some type (see O’Clearly 2004). In a sign of hope, and despite the Rudd Government's contradictory position on disability, one of the Rudd Labor Government's first acts was to write to disability advocacy organisations across the country removing all media controls from state funding agreements (Macklin 2008) and releasing an additional $\$ 500,000$ to expand access to disability advocacy services (Shorten 2008). Such actions, coupled with a plethora of consultation strategies to reform some segments of the disability services sector have been applauded by the Australian disability movement as a chance of renewal and re-collectivisation of their struggles for justice. This is probably most exemplified by a new network of disability advocacy organisations emerging across the country. The Disability Advocacy Network Australia (DANA 2009) effectively bypasses those disability peak 
institutions established during the Howard Years of Government reclaiming the political space for mobilisation, contestation and activism.

\section{Acknowledgements}

Thanks to Janaka Biyanwila, Ethan Blue, Mike Clear, Shae Garwood, Lucy Fiske and Helen Meekosha for their comments on earlier drafts of this article and the Fogarty Foundation for funding the documentary research and interviews.

\section{References}

Ambramovitz, M. (2006) Welfare reform in the United States: gender, race and class matter, Critical Social Policy, 26(2), pp. 336-364.

Anthony, L. (2000) \$16 million disability employment trial (Media Release). on-line. Available HTTP:

http://www.fahcsia.gov.au/internet/minister2.nsf/content/m16milemptrial.htm

Australian Council for the Rehabilitation of the Disabled (ACROD) (now National Disability Services) (2004b) Caution required in drawing conclusion from the Job Network Pilot (Media Release) 24 November 2004.

Australian Council for the Rehabilitation of the Disabled (ACROD) (now National Disability Services) (2005) AIRC issues its decision on wage regulation, 6 September 2005.

Australian Health Associates (AHA) (2002) Complete Report: Case Based Funding Trial Final Evaluation Report (Canberra: Commonwealth of Australia)

Australian Parent Advocacy Inc. (APA) (2005) Submission to the AIRC on Safety-Net hearings for people with a disability employed in Australia's business services (Bundaberg: APA)

Baker, K. CEO, ACROD, Community Affairs Senate Committee, 25 September 2001, CA4.

Barnes, C. \& Mercer, G. (20050 Disability, work and welfare: challenging the social exclusion of disabled people. Work, Employment and Society, 19 (3) pp. 527-545.

Bernstein, M. (2005) Identity politics. Annual Review of Sociology, 31, pp. 47-74.

Bills Digest No. 125 (2002) Family and Community Services Legislation Amendment (Disability Reform) Bill (No.2) 2002 (Canberra: Department of the Parliamentary Library). 
Bills Digest No. 125 (2003) Family and Community Services Legislation Amendment (Disability Reform) Bill (No.2) 2002 [No.2] ( Canberra: Department of the Parliamentary Library).

Bills Digest No.157 (2001) Family and Community Services Legislation Amendment (Disability Reform) Bill 2002 (Canberra: Department of the Parliamentary Library).

Bhaskar, R (1993) Dialectic: The pulse of freedom (London:Verso).

Burawoy, M (2003) For a Sociological Marxism: The complementary convergence of Antonio Gramsci and Karl Polanyi, Politics \& Society, 31, pp. 193-261.

Campbell, J. \& Oliver, M. (1996) Disability politics: understanding our past, changing our future (London: Routledge).

Carney, T. (2007). Travelling the 'work-first' road to welfare reform, Just Policy, 44, pp.12-20.

Charlton, J. I. (1998) Nothing about us without us: disability oppression and empowerment (Berkley: University of California Press).

Clear, M. \& Gleeson, B. (2002) Disability and materialist embodiment, Australian Journal of Political Economy, 49. pp. 34-55.

Clear, M. (2000) Promises, Promises: Disability and the terms of inclusion (Sydney: Federation Press).

Cook, J, Roche, M., Williams C.C \& Windebank, J. (2001) The evolution of active welfare policies as a solution to social exclusion in Britain, Journal of European Studies, 9(1), pp.13-26.

Cooper, M. (1999) The Australian disability rights movement lives, Disability \& Society, 14(2), pp. 217-226.

Disability Advocacy Network Australia (DANA) (2009) DANA Board Communique, 23 September 2009.

Disability Employment Action Centre (DEAC) \& National Council on Intellectual Disability (NCID) (2003) Safety Net Review 2003: Written Submission (Melbourne: DEAC)

Department of Employment and Workplace Relations (DEWR) (2004) Jobnetwork disability support pension pilot: interim evaluation report (Canberra: Australian Government).

Department of Family and Community Services (FaCS) (2000) A viable future:

Strategic imperatives for business services (Canberra: Commonwealth of Australia).

Department of Family and Community Services (FaCS) (2002b) Budget 2002-2003 What's new, What's different (Canberra: Commonwealth of Australia). 
Department of Family and Community Services (FaCS) (2003) Implementing Case Based Funding: report on the service provider consultation process (Canberra: Commonwealth of Australia).

Donati, P (1984) Organisation between movement and institution, Social Science Information, 23(4/5), pp. 837-859.

Dowse, L. (2007) Stand up and give 'em the fright of their life. Ph.D. dissertation, Arts faculty, University of New South Wales.

Evans, J. (1989) New directions in disability: a report on the progress of the 'deserving poor', in Kennedy, R (Ed.) Australian welfare, pp. 242-262 (South Melbourne: Macmillan)

Finn, D. (2000) From full employment to employability: a new deal for Britain's unemployed, International Journal of Manpower, 21(5), pp. 384-395.

Fiske, L.\& Briskman, L. (2007) Rights and Responsibilities: Reclaiming Human Rights in Political Discourse, Just Policy, 43, pp. 50-54.

Galvin, R. (2004) Can welfare reform make disability disappear? Australian Journal of Social Issues, 39(3), pp. 343-353.

Goggin, G. \& Newell, C. (2000) An end to disabling policies? Toward enlightened universal service, The Information Society, 16(2), pp. 127-133.

Goggin, G. \& Newell, C. (2005) Disability in Australia: exposing a social apartheid (Sydney: The University of New South Wales Press).

Goodin, R. (2002) Structures of mutual obligation, Journal of Social Policy, 31(4), pp. 579-596.

Goodin, R., Headey, B., Muffels. \& Dirven, H. (1999) The real worlds of welfare capitalism (Cambridge: Cambridge University Press).

Hamer, J (2009) Pension Review Report Department of Families, Housing, Community Services and Indigenous Affairs, Canberra.

Haylett, C. (2003) Remaking labour imaginaries: social reproduction and the internationalising project of welfare reform, Political Geography, 22(7), pp. 765-788.

Howard, J. (2004) \$99 million Safety Net for Disability (Media Release), 21 April, Department of Prime Minister and Cabinet.

Humpage, L. (2007). Models of work, disability and welfare in Australia Social Policy and Administration 41 (3): 215-231.

Hughes, B. (2009) Disability activisms: social model stalwarts and biological citizens, Disability \& Society, 24(6), pp.677-688. 
Lister, R. (2001), Towards a citizens' welfare state: The $3+2$ 'R's of welfare reform, Theory, Culture \& Society, 18(1), pp. 91-111.

Maddison, S. 2007. Redefining Democracy, in C. Hamilton \& S. Maddison (Eds) Silencing Dissent: How the Australian Government is Controlling Public Opinion and Stifling Debate pp. 24-40 (Sydney: Allen \& Unwin).

Maddison, S. \& Scalmer, S. (2006) Activist Wisdom: practical knowledge and creative tension in social movements (Sydney: UNSW Press).

Malhotra, R. (2005) The politics of the disability rights movement, New Politics, 8(3), pp.3-6.

Macklin, J (2008) Letter to Women with Disabilities Australia Commonwealth of Australia, Canberra (letter to community advocacy service, 4 April 2008)

Martin, G. (2001) Social movements, welfare and social policy: a critical analysis, Critical Social Policy, 21(3), pp. 361-383.

Martin, S. (2007) Welfare reform, the underclass thesis and the process of legitimising social divisions (Melbourne: University of Melbourne).

McInnes, E. (2007) Welfare to work: Creating a new social security exclusion system (Perth: Institute of Advanced Studies).

Meekosha, H. (1999) Disability and human rights, Paper presented at the Attorney General's NGO Forum on Domestic Human Rights, 11 March, in Canberra, Australia.

Meekosha, H. (2001) The politics of recognition or the politics of presence: the challenge of disability, in Sawer, M. \& Zappala, G. (Eds) Speaking for the people: representation in Australian politics, 225-245 (Melbourne: Melbourne University Press).

Meekosha, H. (2002). Virtual activists? Women and the making of identities of disability, Hypatia, 17(3), pp. 67-88.

Meekosha, H. \& Dowse, L. (1997) Enabling citizenship: gender, disability and citizenship in Australia, Feminist Review, 57, pp. 49-72.

Mendes, P. (2008) Australia's welfare wars revisited ( $2^{\text {nd }}$ edition) (Sydney: University of New South Wales Press).

Minkoff, D. (1999) Bending with the wind: strategic change and adaptation by the women's and racial minority organisations, American Journal of Sociology, 104(6), pp. 1666-1703.

Mladenov, T (2009) Institutional woes of participation: Bulgarian disabled people's organisations and policy-making, Disability \& Society, 24(1), pp. 33-45. 
Newell, C. (1996) The disability rights movement in Australia: a note from the trenches, Disability \& Society, 1 (5), pp. 429-432.

Newell, C. (1999). Encountering oppression: the emergence of the Australian disability rights movement, Social Alternatives, 18(1), pp. 47-52.

Ohlin, J (1999) Unmet need in disability services: shortfall or systemic failure?

Parliamentary Library of Australia, Canberra available at http://www.aph.gov.au/library/pubs/cib/1999-2000/2000cib06.htm (accessed online on 7 september 2009).

Peck, J. (2001) Workfare States (New York: The Guildford Press).

Peck, J. \& Theodore, N. (2000) Beyond ‘employability', Cambridge Journal of Economics, 24(6), pp.729-749.

People with Disabilities (2009) National leadership workshop for Aboriginal people with disability PWD E-Bulletin, 57(September/October), pp.13.

Pini, B., Brown, K. \& Previte, J. (2004) Politics and identity in cyberspace: a case study of Australian women in agriculture online, in W. Van de Donk, B.D. Loader, P.G. Nixon and D. Rucht (Eds) Cyberprotest: new media, citizens and social movements, pp. 259-275 (London: Routledge).

Salthouse, S. (2005) 'Jumping through hoops': welfare and industrial relations reform implications for women with disabilities. Paper presented on behalf of Women with Disabilities Australia at the 'What Women Want' workshop, 12 July, in Canberra, Australia. online. Available HTTP: http://www.wwda.org.au/w2wjuly05.htm

Senate Hansard. 1999. Senate Hansard: official parliamentary debates 14 October, pp. 9727-9730 (Canberra: Commonwealth of Australia)

Senate Community Affairs Legislation Committee 2003, Answers to estimates questions on notice: Family and Community Services Portfolio, 12 February 2003 (Canberra: Commonwealth of Australia)

Shapiro, J.P. (1993) No pity (New York: Three Rivers Press).

Shaver, S. (2002). Australian welfare reform: from citizenship to supervision, Social Policy and Administration, 36(4), pp. 331-345.

Shaver, S. (2001) Australian welfare reform: from citizenship to social engineering, Australian Journal of Social Issues, 36, pp. 277-293.

Shorten, B. (2008) \$500,000 to expand advocacy for people with disability, Australian Gvoernment Media Release (31 October 2008) available at: http://www.billshorten.fahcsia.gov.au/internet/billshorten.nsf/content/expand_advoca cy_31oct08.htm Accessed on 22 October 2009. 
Shorten, B. (2009) Launch of the Australian Disability Enterprises Website, Australian Government, Canberra Available at: http://www.billshorten.fahcsia.gov.au/internet/billshorten.nsf/content/disability_enter prises_site_24april09.htm Accessed on: 07 September 2009.

Skeggs, B. (2004) Class, self, culture (London: Routledge).

Smith, K. (2003) Pushing boundaries: the exclusion of disability rights groups from political influence in Victoria, Australian Geographer, 34(3), pp. 345-354.

Soldatic, K. (2009) Disability and the Australian neoliberal workfare state (1996 2005) Unpublished PhD (Perth: University of Western Australia)

Soldatic, K. and Pini, B. (2009) The three D's of welfare reform: disability, disgust and deservingness Australian Journal of Human Rights 15(1), in press.

Tarrow, Sidney. 1983, Struggling to Reform: Social Movements and Policy Change during Cycles of Protest, Western Societies Paper 15 (Ithaca: Cornell University).

Tilly, C. (1978) From mobilisation to revolution ( Reading, MA: Addison-Wesley).

Tilly, C. (2006) Regimes and repertoires (Chicago: University of Chicago Press).

Tucker, K. (1991) How new are the new social movements? Theory, Culture \& Society, 8(2), pp. 75-98.

Wilson, S. \& Turnbull, N. (2001) Wedge politics and welfare reform in Australia, Australian Journal of Politics and History, 43(3), pp. 384-404.

Yeatman, A 1990 Activism and the policy process (Sydney: Allen \& Unwin)

Zames Fleischer, D. \& Zames, F. (2001) The disability rights movement: from charity to confrontation (Philadelphia: Temple University Press). 